\title{
An Economic and Statistical Analysis of Extrabudgetary Funds in the Russian Federation
}

\author{
Nigmatullina G.R. \\ Department of accounting, statistics and information \\ systems in Economics \\ Bashkir State Agrarian University \\ Ufa, Russia \\ nigmatullina419@yandex.ru
}

\author{
Girfanova I.N. \\ Department of accounting, statistics and information \\ systems in Economics \\ Bashkir State Agrarian University \\ Ufa, Russia \\ irina13091970@mail.ru
}

\author{
Zalilova Z.A. \\ Department of accounting, statistics and information systems in Economics \\ Bashkir State Agrarian University \\ Ufa, Russia \\ zalza13@mail.ru
}

\begin{abstract}
The system of mandatory insurance in the Russian Federation is represented by three funds. They are the only form of social protection of the population. An analysis of the results of activities of these extrabudgetary structures will make it possible to assess the effectiveness of the current system of formation and use of extrabudgetary funds. The foreign experience in this field provides exposure to responsibility between an employee and their employer. It should be taken into account that Russia allocates revenues of extrabudgetary funds on the social basis provided by employers, without participation of employees. Joint and several responsibilities are also possible. The results of the study revealed that the existing social insurance system has the potential for development and adaptation to modern conditions, market and society requirements. Adopting the positive experience of foreign countries and highlighting the factors that have an impact, it is possible to adjust the items of income and expenditure of each of the funds.
\end{abstract}

Keywords - extra-budgetary funds; social protection; income; expenditure; analysis.

\section{INTRODUCTION}

Social protection of the population is of paramount importance for the effective development of the state. That is why issues, related to the development of basic social funds being extrabudgetary in nature, are becoming more acute. Their real condition provides welfare and social guarantees to the population. At the current stage of development of the Russian Federation there are three federal social extrabudgetary funds: FSS (social insurance fund), PFR (Pension Fund), FOMS (federal mandatory health insurance fund). The development of these funds goes back to early 1990. The experience gained makes it possible to find new directions for functioning of these funds.

\section{LITERATURE REVIEW}

In the light of contemporary realities, especially in economies in transition as well as in developing ones, more and more researchers are working on social security and welfare. The studies are comprehensive and wide-ranging. Some researchers delve more into theoretical issues, while others, on the contrary, study practical experience. They try to adopt something new and apply to their state in order to improve the lives of their contemporaries. Thus, the study of Antia F., Lanzara A. P. V. describes the Chilean, Uruguayan and Brazilian systems [1]. Brodmann S., Jilloson I., Hassan N, outline changes in social insurance in Jordan [2]. Sanchez Martin A.R. gives special emphasis to the Spanish pension system [3]. Cai Y., Cheng Y. [4], Remington T. F. [5] focus on pension reform in China. Bielawska, Guardiancich, Fultz E., Schmähl W., Horstmann S. provide an overview of the insurance systems in European countries [6]. Among the Russian scientists studying social insurance we can highlight N. Grishchenko. The works of this researcher are devoted to the comparative analysis of pension reforms in Belarus, Kazakhstan and Russia [7]. Studies of Góra M., Rohozynsky O., Sinyavskaya O. [8] focus on the prospects of pension provision in Russia and Ukraine.

The development of a social extrabudgetary fund is not possible without political influence. The works on pension provision $[9,10,11]$ prove that every author has their own way to stipulate the need for constant reforming of the pension system. Studies of the health insurance market in the European Union demonstrate the practice of private financing of the health care system $[12,13,14,15,16]$. And this practice is gradually becoming common in our country as well.

\section{RESEARCH METHODOLOGY}

The real state of extrabudgetary social funds of Russia was studied on the basis of official statistics, publicly available on 
The same trend of income during this period is tracked for

the website of the Federal State Statistics Service of the Russian Federation [17]. Economic and statistical tools were applied to the collected data. The analysis of the state was carried out in dynamics for the period from 1999 to 2018. The annual time intervals were consolidated into five years with their average values being calculated. This was done in order to eliminate excessive figures.

\section{RESULTS}

The analysis of the average figures given in relation to the Pension Fund shows that in the first three five-year periods revenues exceeded expenditures. It should be noted that the Pension Fund collected revenues not only from insurance premiums and tax payments, but also from the Federal budget. Moreover, the share of funds from the Federal budget in the first five-year plan was $6.4 \%$, and more than $45 \%$ in subsequent five-year plans, reaching $50 \%$ in 2009-2013. In the last period of time from 2014-2018 the relation between income and expenses changed with the latter exceeding income by $2.7 \%$. This is due to the formation of revenues to the pension Fund and the provisions of the Tax code entered into force in the studied period.

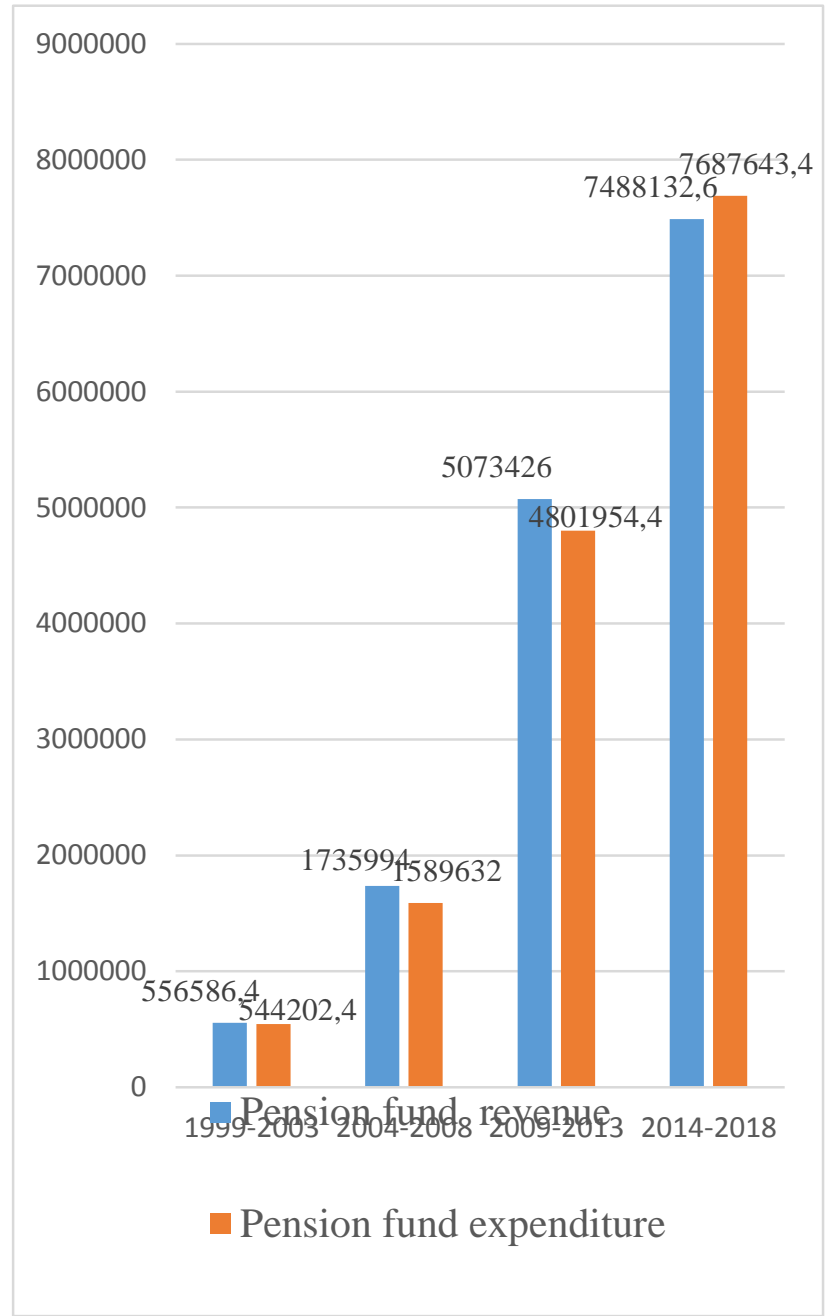

Fig. 1. Average annual levels of revenues and expenditure of the Pension Fund of the Russian Federation, mln. RUB. the social insurance fund of the Russian Federation, the data are shown in figure 2 .

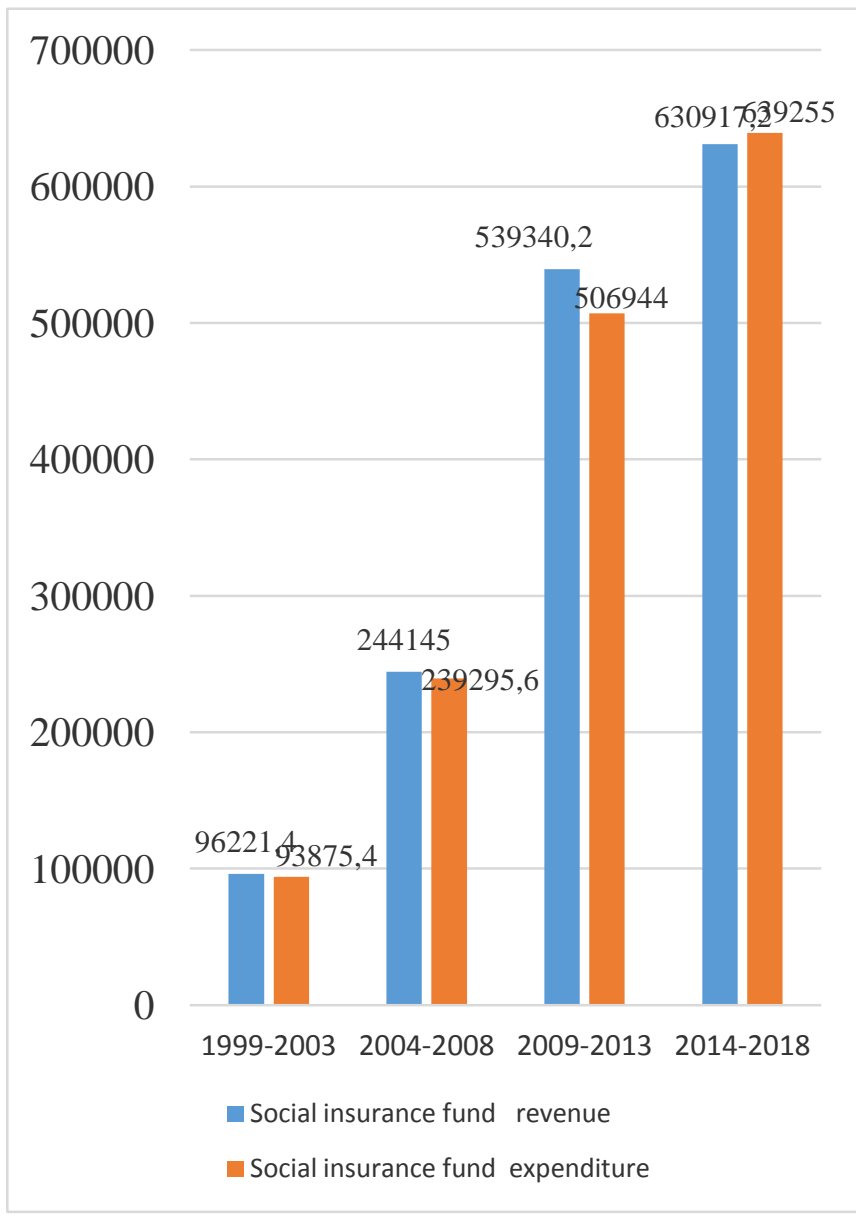

Fig. 2. Average annual levels of revenues and expenditure of the Social Insurance Fund of the Russian Federation, mln. RUB.

The difference between the social insurance fund and the pension fund is in the share of Federal budget revenues. Revenues to the social insurance fund were much lower and averaged $0.7 \%$ in $1999-2003,10.2 \%$ in $2004-2008,25.1 \%$ in $2009-2013,6.1 \%$ in $2014-2018$.

The situation with the compulsory health insurance fund is identical to the above mentioned funds. Spending in the last five years exceeded revenues by $0.3 \%$. There is a constant decrease in the participation of the Federal budget in its formation.

\section{CONCLUSIONS}

The formation of the studied extrabudgetary funds is influenced by a number of factors. The main ones are the interest rate being payable on income; the level of gross domestic product, showing the annual result of the country's economy; the inflation rate; the income level of the population. It is the effectiveness of these factors that should be paid attention to for the successful formation of extrabudgetary social funds. 
[8] Góra M., Rohozynsky O., Sinyavskaya O. Pension reform options for Russia and Ukraine: a critical analysis of available options and their expected outcomes, ESCIRRU Working Papers. 2010, 25, pp. 1-66.

As foreign scientists claim, the results of activities of extrabudgetary social funds on the territory of the Russian Federation received on the enlarged periods confirm the need to regulate this segment $[2,7,8]$. The compulsory health insurance fund is of particular interest to every resident of the country. We must apply the experience of foreign countries in practice to adjust the work of the health care system completely $[12,13,14,16]$.

\section{References}

[1] Antia F., Lanzara A. P. Multi-pillared social insurance systems: The post-reform picture in Chile, Uruguay and Brazil, "International Social Security Review". 2011, 64(1), pp. 53-71.

[2] Brodmann S., Jilloson I., Hassan N. Social Insurance Reform in Jordan. Awareness and Perceptions of Employment Opportunities for Women, Social Protection \& Labor, 2014, 1402.

[3] Sanchez Martin A.R. Endogenous retirement and public pension system reform in Spain, "Economic Modelling". 2010, 27, pp. 336-349.

[4] Cai Y., Cheng Y. Pension reform in China: challenges and opportunities, "Journal of Economic Surveys". 2014, 28(4), pp. 636651.

[5] Remington T. F. Pension Reform in Authoritarian Regimes: Russia and China Compared. 2015, URL: http://polisci.emory.edu/home/documents/papers/pensionreform$\% 20$ authoritarian-regimes.pdf.

[6] Bielawska K. Sustainability of structural pension reforms in the CEE countries - experiences and lessons, "Insurance Review". 2014, 4, pp. 111-122.

[7] Grishchenko N. Pensions after pension reforms: a comparative analysis of Belarus, Kazakhstan, and Russia, "Procedia Economics and Finance”. 2016, 39, pp. 3-9.

[9] Remington T. F. Pension Reform in Authoritarian Regimes: Russia and China Compared. 2015. URL: http://polisci.emory.edu/home/documents/papers/pensionreform$\% 20$ authoritarian-regimes.pdf.

[10] Fornero E. Economic-financial literacy and (sustainable) pension reforms: why the former is a key ingredient for the latter, "Bankers, Markets \& Investors". 2015, 134, pp. 6-16.

[11] Wagner H. Pension Reform in the New EU Member States. Will a Three-Pillar Pension System Work? "Eastern European Economics". 2005, 43(4), pp. 27-51.

[12] Borda M. The role of private health financing in Central and Eastern Europe. Economy. 2008, 83, pp. 100-109. Golinowska S., Sowa A. и Toпор-Mądry R. 2006.

[13] Health and health systems in Central and Eastern Europe: Bulgaria, Estonia, Poland, Slovakia and Hungary. ENEPRI research report No. 31.

[14] Sagan A. Panteli D, Borkowski W., Dmowski M., Domański F., Czyzewski, M., ... Busse R. Poland: health system overview. Health systems in transition. 2011, 13(8), pp. 1 - 193. European Observatory on health systems and policies, world health organization

[15] Wagstaff A. \& Moreno-Serra R. Europe and Central Asia " a great post-Communist social health insurance experiment with: Cumulative impact on outcomes in the health sector. Journal of Health Economics. 2009, 28 (2), pp. 322 - 340.

[16] Nemec J., Tsankar S., Kostadinova T., Malyj I., \& Darmopilova Z. Health financing: what can we learn from the experience of Central and Eastern Europe? Administrative culture. 2013, 14 (2), pp. 212 - 23.

[17] Alexsandr S. Kuznetsov. Russian Professor's meeting. Russian Journal of Physical Education and Sport. 2019, 14(1), pp. 17-22. DOI: 10.14526/2070-4798-2019-14-1-18-24

[18] Federal state statistics service. Access mode https://www.gks.ru/ 